\title{
NOTES ON EUSTROPHUS BICOLOR FABR., BRED FROM FUNGI (COLEOPTERA).
}

\author{
By HaRry B. Weiss, \\ New Brunswick, N. J.
}

This species, which according to Smith ${ }^{1}$ occurs throughout New Jersey from September until the following June, was recently bred from larvæ found feeding in Pleurotus sapidus ${ }^{2}$ at Monmouth Junction, N. J., on May 30 and in Polyporus squamosus ${ }^{2}$ at Union, N. J., on May 20. The larvæ collected at Monmouth Junction became full grown during the first week of June and pupated, this stage requiring about one week. The infested fungi which were kept in glass beakers dried out considerably and the larvæ left them and pupated in the bottoms of the containers. It is, therefore, not known where pupation takes place under natural conditions. As the fungi were more or less destroyed by the larvæ, it seems likely that the quiescent stage is passed in the soil or under bark.

Pleurotus sapidus which belongs to the family Agaricaceo is a common saprophytic form occurring on dead, deciduous wood and is one of the edible species closely resembling Pleurotus ostreatus, the oyster mushroom. Polyporus squamosus is a member of the family Polyporacea and occurs on living, deciduous trees according to Overholts ${ }^{3}$ and on dead parts of living, deciduous trees according to Stevens. ${ }^{4}$ Stevens also states that the mycellium causes a white rot of nut, ornamental and fruit trees particularly maple, pear, oak, elm, walnut, linden, ash, birch, chestnut and beech.

In the case of Pleurotus sapidus, the larvæ fed on the context and stipe, completely riddling them. In Polyporus squamosus both the context and tubes were eaten. Other species of fungi on which adults only were found are Polyporus betulinus, Princeton Junction, N. J., April 24; Polyporus versicolor, Riverton, N. J., May 5; and Dadalia confragosa, Kingston, N. J., May 8; all belonging to the Polyporacea. Up to the present, however, larvæ have been found only in the two species mentioned in the first part of these notes.

1 Smith, J. B., Insects of New Jersey (N. J. State Mus. Rept. 1909).

2 Identified by Mr. Erdman West.

${ }^{3}$ Overholts, L. O., Polyporaceæ of Mid. Wes. U. S. (Wash. Univ. Studies, III, I, 1, p. 17).

${ }^{4}$ Stevens, F. L., Fungi Which Cause Plant Disease (1913). 


\section{Eustrophus bicolor Fabr.}

Full-grown Larva. Length 6 to $7 \mathrm{~mm}$. Width 1.5 to $1.8 \mathrm{~mm}$. Elongate, subcylindrical, sparsely hairy, whitish or sordid white except head which is dark and the dorsal surfaces of the thoracic and abdominal segments which bear dark brown to black subrectangular transverse areas giving the dorsal surface a banded appearance. Head large; antenna 4-segmented, each segment subcylindrical, basal segment widest, second segment shortest, third segment bearing the slender fourth segment and a minute spine. Maxillary palpus subcylindrical, 3-segmented, almost as long as antenna, first and second segments subequal in length, third segment one and one-half times length of first. Labial palpus subcylindrical, short, 3-jointed, joints equal in length. Abdominal segments one to eight slightly produced at sides. Ninth abdominal segment bears two dorsal, prominent, reddish-brown tubercles, each tipped with a chitinous hook slightly curved anteriorly. Bases of dorsal tubercles covered with minute, dark tubercles each bearing a hair. Legs well developed, sparsely hairy, anterior surfaces of femora well supplied with minute spines. Dorsal surface of head bears a subcircular, faintly impressed line. Faint, median, whitish line on dorsal surface of first and second thoracic segments sometimes continuing on abdominal segments. Spiracles on second thoracic and abdominal segments one to eight. Abdominal spiracles just below dorsal colorations.

Pupa. Length 5 to $6 \mathrm{~mm}$. Width, $2 \mathrm{~mm}$. Whitish, elongateoval, rounded anteriorly, gradually tapering posteriorly. Head and thorax covered with minute tubercles, each bearing a long hair. Transverse patches of similar hair-bearing tubercles on dorsal surfaces of remaining segments. Ventral surface almost devoid of hairs.

Adult. This was described by Fabricius in 1798 (Ent. Syst. I, p. 497). Sharp ${ }^{1}$ states that about 200 species of Melandryidoe are known, chiefly from temperate regions and that they frequent dry wood or fungi. He also says that the few described larvæ are varied in their details and cannot be generalized at present. Blatchley $^{2}$ writes that $E$. bicolor is common throughout Indiana, January 19 to September 20 and found beneath bark especially that of fungus covered logs.

1 Sharp, D., The Cambridge Natural History, Insects, Part II, p. 265.

2 Blatchley, W. S., Coleoptera of Indiana, 1910. 

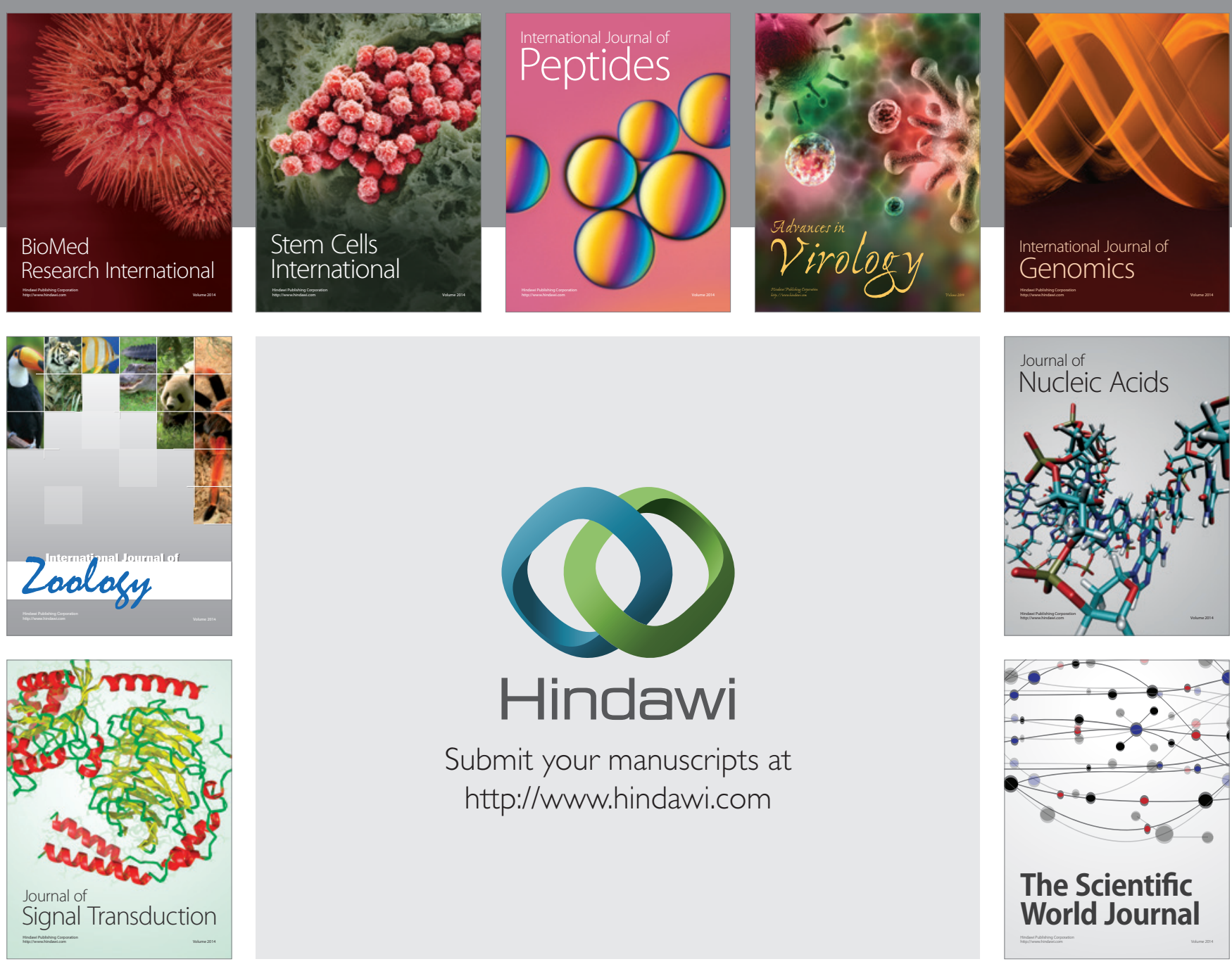

Submit your manuscripts at

http://www.hindawi.com
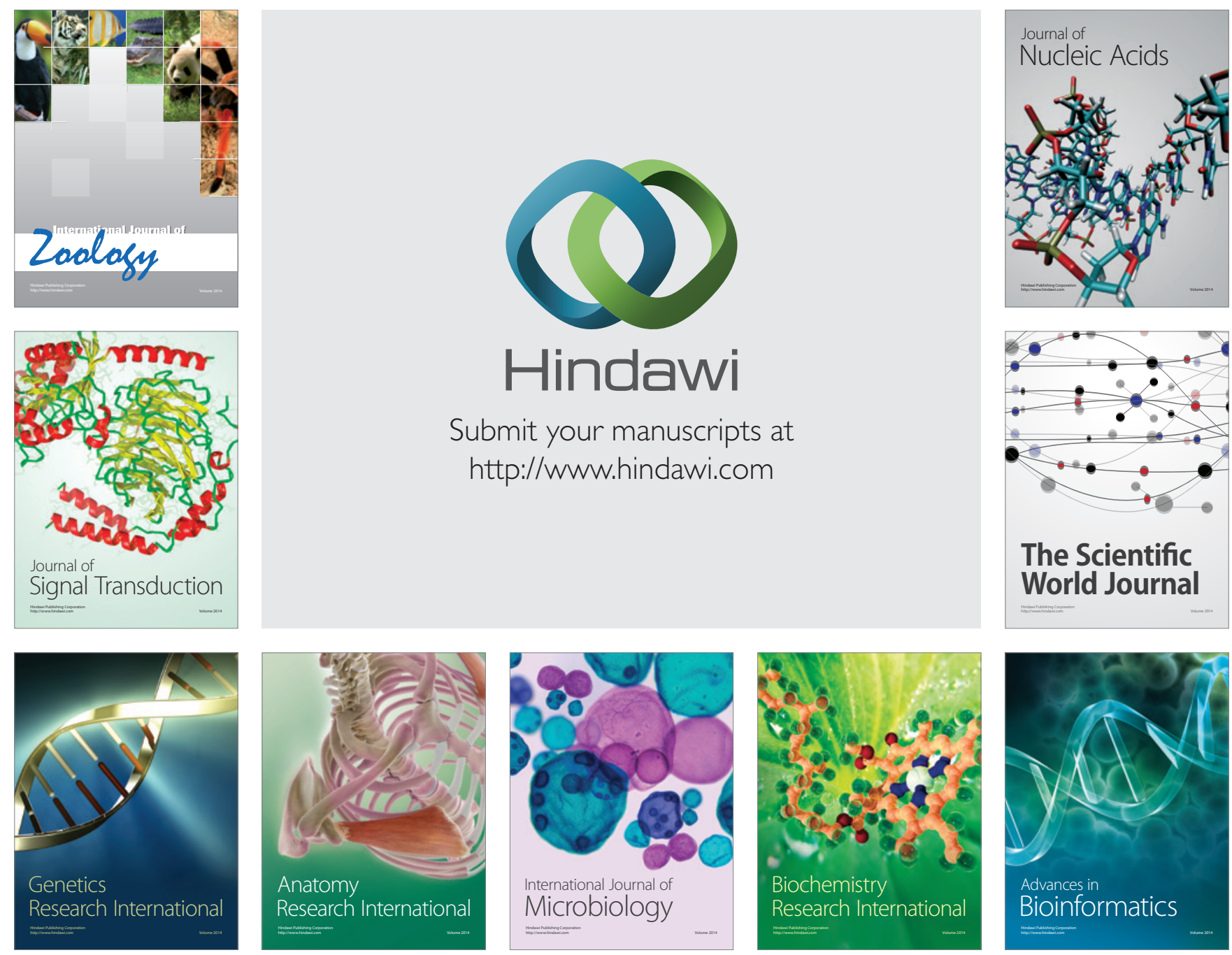

The Scientific World Journal
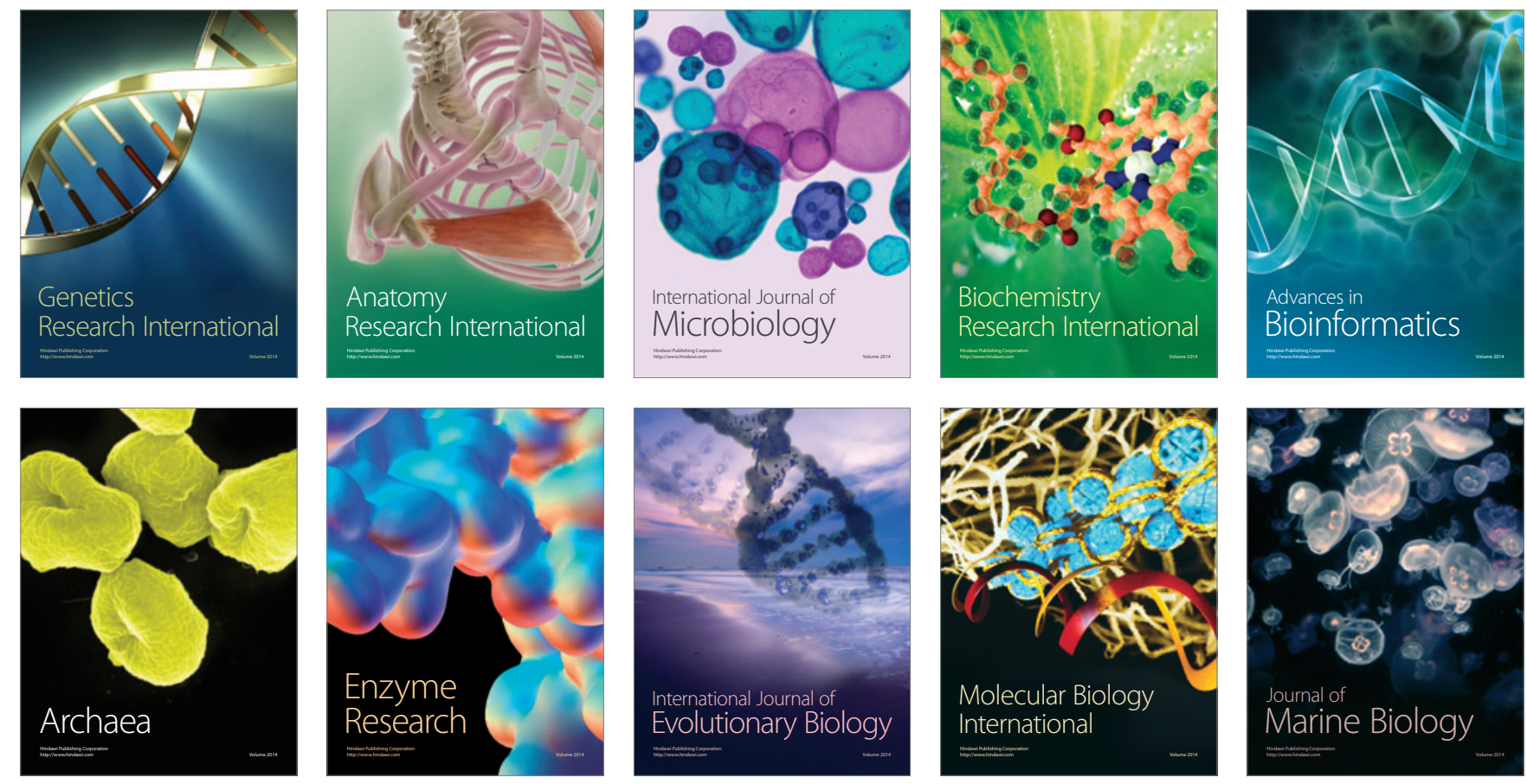